responsible. Blood samples were collected beginning on the day following the last dose of pimozide and analysed by a sensitive and specific radioimmunoassay (Michiels, Heykants, Knaeps and Janssen, 1975). The results are shown in the Table.

TABLE

Serum pimozide concentration following withdrawal of the drug

\begin{tabular}{lcc}
\hline Date & Time & $\begin{array}{c}\text { Serum pimozide } \\
(\mathrm{ng} / \mathrm{ml})\end{array}$ \\
\hline 18.3 .81 & 13.00 & 17.5 \\
19.3 .81 & 09.00 & 16.8 \\
20.3 .81 & 09.15 & 15.7 \\
23.3 .81 & 09.00 & 10.5 \\
27.3 .81 & 09.00 & 7.0 \\
\hline
\end{tabular}

The log-linear relationship between pimozide concentration and time has a regression coefficient of $0.99(\mathrm{P}<0.001)$. The slope of this line gives a pimozide half-life in this patient of 154 hours. The value previously reported following multiple dosing in hospital patients is $55 \pm 7$ hours (McCreadie, Heykants, Chalmers and Anderson, 1979).

Half-life is determined partly by the rate of clearance and partly by the volume of distribution. Since there was no reason to suppose that the volume of distribution was greatly altered in this patient the prolonged half-life is likely to have been the result of decreased pimozide clearance from the body.

Pimozide is metabolized in the liver by oxidative N-dealkylation (Soudijn and Van Wijngaarden, 1969). The patient had normal liver function and none of the drugs which were co-administered around the time of this adverse reaction has been reported to cause enzyme inhibition (Griffin and D'Arcy, 1979). Recently, oxidative metabolism has been shown to be under genetic control with about 10 per cent of the population being poor metabolizers (Mahgoub, Idle, Dring, Lancaster and Smith, 1977). The limited data which we present in this case report suggests that pimozide oxidation could also be under this type of control with our patient being a poor metabolizer. The patterns of pimozide metabolism in psychiatric patients would be worthy of further investigation.

F. A. LOGAN

Gartnaval Royal Hospital, Glasgow

R. N. HERRINGTON

Dumfries and Galloway Royal Infirmary

M. M. S. MACKIE

Glasgow University,

P. C. RUBIN

Stobhill General Hospital, Glasgow G21 3UW
References

Griffin, J. P. \& D'Arcy, P. F. (1979) Adverse Drug Interactions. Bristol: Wright.

McCreadie, R. G., Heykants, J. J. P., Chalmers, A. \& ANDerson, A. M. (1979) Plasma pimozide profiles in chronic schizophrenics. British Journal of Clinical Pharmacology, 7, 533-4.

Mahgoub, A., IDLe, J. R., Dring, L. G., Lancaster, R. \& SMITH, R. L. (1977) The polymorphic hydroxylation of debrisoquine in man. Lancet, 584-6.

Michiels, L. J. M., Heykants, J. J. P., Knaeps, A. G. \& JANSSEN, P. A. J. (1975) Radioimmunoassay of the neuroleptic drug pimozide. Life Sciences, 16, 937-44.

Pinder, R. M., Brogden, R. N., Sawyer, P. R., Speight, T. M., Spencer, R. \& Avery, G. S. (1976) Pimozide: a review of its pharmacological properties and therapeutic uses in psychiatry. Drugs, 12, 1-40.

Soudijn, W. \& VAN WiJngaARden, I. (1969) The metabolism and excretion of the neuroleptic drug pimozide. Life Sciences, 8, 291-6.

\section{COMMUNITY SCREENING FOR MENTAL ILLNESS}

DeAR SiR,

We were interested to read of "Community Screening for Mental Illness" using an inventory technique (Benjamin et al, Journal, February 1982, $140,174-80$ ). The 60 item GHQ was used and this was further reduced (after a principal components analysis) to a 15 item single factor of the GHQ. It was suggested that this short inventory provides a satisfactory screening instrument. We were not surprised at their success, having previously reported a similar, short questionnaire technique (Donaldson et al, 1969; Kerry et al, 1970). The questionnaire we used consists of the 13 items plus 7 buffer items shown in the Table.

TABLE

Mental Health Questionnaire

1. Do you often want to be with people who will 'cheer you up'?

2. When you go to bed do you lie awake a long time before falling asleep?

3. Have you ever walked in your sleep?

4. Do you feel adjusted to life ?

5. Do you cope fairly well with emergencies?

6. Have you ever fainted or 'blacked out'?

7. Do failures make you work harder?

8. Have you ever done things and, later on, found you don't know you have been doing them?

9. Are you inclined to worry without any reason for doing so?

10. Do you feel you are no good and will never make a success of life?

11. Can you usually fall asleep at any time of the day?

12. Are you upset if people make fun of you?

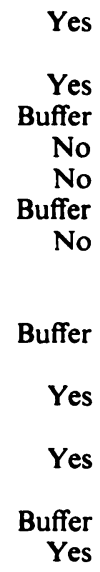

Yes 
13. Do you get downhearted if people don't appreciate you enough?

14. Are there events in your life which you should be able to remember but can't?

15. Do you have periods of feeling irritable when you don't want to see anyone?

16. Can you relax and take it easy when you have time to do so?

17. Are you quick in making decisions?

18. Do you sometimes wake in the night and, through worrying, have difficulty in going back to sleep?

19. Do you make friends easily?

20. Have you ever had a sudden sense of dread and danger for no reason?

This questionnaire was used in the Rotherham 1966 and 1967 multiple health screening clinics. In these clinics 4319 people were screened for mental health and 97.4 per cent of 'cases' were positively identified. In a general practice screening clinic in 1969, 961 people were screened and the resulting accuracy of positive findings was 94 per cent. These results are comparable to those of Benjamin et al, and it can be seen that many of the items in the 2 short questionnaires have a very similar content. This latest paper therefore confirms our earlier view that it is possible effectively to screen for mental illness using a short, unembarrassing questionnaire.

\section{R. J. KERRY}

\section{J. E. ORME}

Northern General Hospital, Sheffield S5 7AU

References

Donaldson, R. J., KerRy, R. J. \& ORme, J. E. (1969) A community mental health screening procedure. Acta Psychiatrica Scandinavica, 45, 198-204.

Kerry, R. J., Orme, J. E. \& WILKes, E. (1970) Personality testing: A new diagnostic aid. The Practitioner, 205, 217-21.

\section{TRILINGUALISM}

DeAR SIR,

The review on bilingualism by $G$. W. Hughes (Journal, July 1981, 139, 25-8) and the letter by $\mathrm{E}$. Zapata (Journal, November 1981, 139, 472) could be enlarged by an observation regarding 'trilingualism' made years ago. At the time, when schizophrenics received routinely a series of 20 ECTs, the highly educated female in her 40s stopped speaking English after 8 or 10 treatments and spoke German, which those around her did not understand. She had immigrated to the United States from Germany. After several more ECTs she began to speak what was first diagnosed as 'word salad'. It was later identified as Russian, and we were told by the patient's husband that she had grown up in Russia from where she moved to Germany and got married. She spoke German without an accent.

What makes this case interesting for interpretation of loss and return of languages is the fact that after ECT had been terminated, the languages returned in reverse order. Four or five days after the last treatment the patient changed from Russian to German and then a few days later started to speak English as fluently as she had done in the beginning of her ECT.

\section{LOTHAR B. KALINOWSKY}

30 East 76th Street,

New York, NY 10021

\section{SENDING SCHIZOPHRENICS TO UNIVERSITY \\ DeAr Sir,}

Dr Crammer (Journal, February 1982, 140, 208) is surely correct to insist that many treated psychotic students are fit to return to their studies after recovery, with or without continued medication; but Dr Dann is right to point out that psychiatrists often recommend return inappropriately or too early, with resultant relapses or academic failure.

Going to university is a major psychosocial transition into an environment that is high on demand and low on support. In my experience, the criterion for return should usually include the best part of a year free from psychotic symptomatology, a period in regular occupation (alas, one cannot nowadays insist on employment) and the successful completion of an academic task. Most students are happy to accept these conditions as being in their own best interests. Ideally, universities should accept such students back on the recommendation of their own medical staff, who would of course take account of the reports of treating psychiatrists; however, the ruthless cutting back of University Health Services under way in many places may make this ideal unattainable in the future.

ANTHONY RYLE

The University of Sussex,

Health Service,

Falmer, Brighton, Sussex

\section{ERRATUM}

"Plasma Growth Hormone and Prolactin Responses to Apomorphine" (Kolakowska et al, Journal, November 1981, 139, 408-12). The second figure referred to in this paper was unaccountably omitted. Photocopies of the original are available from the editorial office of this Journal on request. 